\title{
TELO A EMÓCIE V KRÁTKEJ PRÓZE MARGITY FIGULI ${ }^{1}$
}

\section{Body and Emotions in Short Prose of Margita Figuli}

Keywords: body, emotions, love, metaphor, M. Figuli, Slovak Naturism

Contact: Slovenská akadémia vied; ludmila.horka@gmail.com

\section{Úvod}

V literatúre sa emóciám venuje vel'ký priestor a umelecky zaujímavé sú najmä zobrazenia silných, netypických emócií, často až iracionálnych emočných prejavov. Intenzívne emócie a vypätú citovost' nachádzame aj v próze Margity Figuli, predovšetkým v zbierke krátkych próz Pokušenie (1937).

Knižný debut Margity Figuli - zbierka noviel Pokušenie vyšla v roku 1937 v nakladatel'stve Leopolda Mazáča v Prahe a obsahovala výber 10 prozaických textov. Expresívne názvy noviel (napr. Extáza, Víchor, Príval, Strmina) prezrádzajú, že Figuli sa sústredila na vypäté psychické a existenciálne situácie a narušenú harmónia v živote postáv. Dobová kritika prijala zbierku Pokušenie vel'mi pozitívne (Š́utovec 2011: 470_ 472).

Vo svojich textoch Figuli tematizuje skryté vášne, citové trápenie i sociálne problémy predovšetkým ženských hrdiniek. Dej noviel je lineárny, neobsahuje výraznejšie vonkajšie zvraty a vedl'ajšie línie. Postavy vo väčšine textov riešia reálne či zdanlivé dilemy, ktoré sú zamerané intelektuálne, sociálne alebo mravne. Postavy vo svojich snaženiach, túžbach a snoch narážajú na limity, ktoré vyplývajú z nejakého „zákona“, „tradície“, „rozumu“. Pre tieto texty je typické výrazné používanie lyrizačných techník $\mathrm{v}$ reči rozprávača, prehovoroch postáv a autorskom opise prostredia. Jazyk próz je rytmicky organizovaný, s bohatým využitím metafor a poetickými opismi prostredia.

Vypätá citovost' a senzuálnost' charakteristická pre tieto texty sú vhodným materiálom na skúmanie emócií v literatúre. Dôrazná zmyslovost' a uplatňovanie lyrických postupov a prvkov situujú zbierku Pokušenie do línie podobných próz

\footnotetext{
${ }^{1}$ Príspevok vznikol v rámci projektu VEGA 2/0045/18, Emócie v literatúre: kognitívnovedný pohl’ad.
} 
medzivojnového obdobia, ktorú dobová kritika označila pojmom lyrizovaná próza. (Šútovec 2005: 210-212) Tento všeobecný pojem neskôr prehodnotil Oskár Čepan (1977), ktorý navrhol presnejšiu periodizáciu medzivojnovej slovenskej prózy a vymedzil naturizmus ako vyvrcholenie lyrizačných tendencií v slovenskej próze toho obdobia. Tým sa Figuli zaradila k hlavným predstavitel'om naturizmu (Čepan 1977: 43$54)$.

Emócie opisuje nemecká literárna teoretička Simone Winko (2003) ako komplexný fenomén, v ktorom možno odkryt' viaceré dimenzie: fenomenologickú kvalitu, kognitívnu zložku, fyziologické symptómy a funkciu motivovat' ku konaniu. Emócie patria k biologickej výbave človeka, sú evolučne ukotvené a človek ich vníma bezprostredne ako subjektívnu formu precit'ovania. Zároveň sú však kultúrne podmienené a formované, kultúrne normy ovplyvňujú primeranú formu vyjadrenia emócí́.

K najdôležitejším médiám artikulácie emócií patrí jazyk, ktorý umožňuje emócie intersubjektívne vyjadrit' a tematizovat'. V literárnych textoch sa na sprostredkovanie emócií využívajú jazykové prostriedky na rôznych úrovniach: zvukovej, morfologickej, syntaktickej, lexikálnej či obraznej. Emócie sú teda do jazyka kódované (Winko 2003: 104-109).

Subjektívne emocionálne prežívanie sa niekedy vhodnejšie vyjadrí pomocou metafor. Nie sú to len štylistické prostriedky, ale pomáhajú konceptuálne uchopit' t’ažko opísatel'né vnútorné stavy. Sú ukotvené v základnej skúsenosti človeka, ktorú získal $\mathrm{v}$ tele a prostredí. Konceptuálna metafora ako ju zadefinovali George Lakoff a Mark Johnson (1980) je nástroj myslenia a poznávania. Jej základným princípom je mapovanie, projekcia prvkov zo zdrojovej domény na ciel'ovú doménu, ktorá je zväčša abstraktnejšia. Konceptuálna metafora sa manifestuje v jazyku vo forme metaforických jazykových výrazov, pričom kreatívne metafory majú zložitejšiu štruktúru. Pri emočných kategóriách zohráva dôležitú úlohu metafora nádoby. Emócie sú teda často konceptualizované pomocou schémy EMÓCIE SÚ TEKUTINY V NÁDOBE (Kövecses 2000: 37; Lakoff 2006: 370).

V príspevku sa zameriam na dva texty zo spomínanej zbierky, ktorých témou je láska - rovnomennú novelu Pokušenie a novelu Extáza. V uvedených dielach budem sledovat' spôsoby zobrazenia lásky a d'alších citov a nálad i to, aké hlbšie schémy možno $\mathrm{v}$ texte identifikovat' a ako sa zobrazované emócie $\mathrm{v}$ texte prepájajú $\mathrm{s}$ telom. Láska patrila $\mathrm{k}$ dominantným témam Margity Figuli. $\mathrm{V}$ zbierke Pokušenie autorka tento cit „skúma“ z rôznych pozícií a v rôznych kontextoch. Vo vybraných dvoch prózach ide o lásku mladú, o prvé zalúbenie, ktoré vyvolá aj mnoho pochybností a otázok. V zásade 
dochádza v oboch prózach ku konfliktu rozumu a citu, morálky a prirodzeného cítenia, ktoré je úzko prepojené s telesnost'ou.

\section{Pokušenie}

V novele Pokušenie (Figuli 2011: 180-187) autorka zobrazila lásku dvoch mladých l'udí, Aleny a Ondra, ktorí spolu trávia horúci letný deň v prírode, na lúke na okraji lesa. Vzájomná náklonnost' $\mathrm{v}$ atmosfére letnej horúčavy prerastá do pocit’ovania telesnej túžby, čo však hned' zavrhujú, pretože sa boja „trestu z neba“. Telesný aspekt lásky je zat’ažený zákazom a hriechom, zároveň je ale podčiarknutá sila prirodzeného pocit'ovania túžby.

Samotný cit lásky je v texte reflektovaný z viacerých strán. Nespája sa len so strachom z previnenia voči morálke, ale aj so strachom zo straty dôvery (,,potom by som vám už nevidela nebo v očiach“) a s obavami z možného sklamania (kamarátka Ol'ga na základe vlastných zážitkov Alenu varovala pred bolestnou skúsenost’ou v láske). Ďalšia rovina, ktorá Ondrovi v zápale presviedčania unikala, je dôležitost' súhlasu partnerky. Alena odoláva prehováraniu, nepodl'ahne nátlaku, ale sebavedomo vie partnerovi signalizovat', že je dôležité aj to, čo chce ona. To Ondra motivuje k reflexii a na krátkej prechádzke, počas ktorej sa na chvíl'u od Aleny vzdiali, sa pokúša upokojit'. Ked' sa vráti, opät' sa v nich ozve túžba a napokon dôjde aj k telesnému zblíženiu.

V atmosfére leta a slnečnej pál'avy sa vášeň v texte znázorňuje hlavne pomocou domény ohňa a tepla, resp. horúčavy. Nápadný je kontrast medzi Ondrom a Alenou, najmä v momente, ked’ Alena čakajúc na Ondreja zaspí. Ondrovo telo je zobrazené ako živé, prebudené, zohriate („horúci príboj citov a cítenia zobúdza mu telo“), v protiklade s tým, ako je opísaná Alena. Ked' ju Ondro nájde spat' v tráve, jej telo sa javí „bez pohybu, bez znaku života“, ako „podoba z kameňa vytesanej ženy“ (Figuli 2011: 185). Alena je na viacerých miestach opísaná ako „studenác a „bez citu“, a teda chlad korešponduje s jej váhavost'ou a rezervovanost'ou v prejavoch citu. Ondro „postrknutý، k úvahe si jej chladné prejavy skúša vysvetlit' inak, hl'adá pre ňu nové atribúty zdôrazňujúce jej nedotknutel’nost': zdá sa mu „svätá“, „krásna“ a „nevinná“. Rozhodne sa obsypat' jej telo kvetmi, ktoré by ju prikryli ako „svieža, zarosená perina“ a zamedzili tak možnost' dotyku. Dar v podobe plného priehrštia kvetov sa však z obavy pred zosmiešnením v krátkosti rozhodne zahodit’ do vody, čím sa ruší aj budovaná atmosféra sakrálnosti.

Ked' Ondro uvidí Alenu po prebudení zo spánku stát' na lúke prežiarenú slnkom, opät' sa v ňom ozvú pocity túžby. I ona je veselá a zvádza ho hrou na naháňačku. Provokujúce pokriky „nechytíte ma“ či „,nedočiahnete“ hravo odkazujú na 
nepolapitel'nost' a nedosiahnutel'nost', ktorou Figuli ženskú hrdinku v predchádzajúcich pasážach charakterizovala. Zároveň sa neguje meravost', „mítvost“" a potvrdzuje „Živost'“ Aleninho tela a jej fyzická zdatnost'.

A. Mráz (1937) vo svojej recenzii označil novelu Pokušenie ako „vibráciu nálad a citových záchvevov“ (Šútovec 2011: 410), čím poukázal na jednoduchost’ deja, čo ale textu neuberá na bohatosti, pretože ide o text $\mathrm{s}$ výrazným emočným potenciálom. Novelu Figuli komponuje ako hru erotického napätia a uvol'nenia, priblíženia a oddialenia, rozbúrenia a upokojenia, rozohriatia a schladenia, násilia a podvolenia. Postavy sa striedavo približujú k sebe a vzd'al'ujú od seba fyzicky a duševne - Ondro opakovane vystiera ruky a schytáva Alenu do náruče, ona sa bráni, vyslobodzuje. Ondrova prechádzka bola vyústením diskusie o citoch a vášni, ked' sa na dlhšiu chvíl'u vzdialil od Aleny. Mala priniest' čas na upokojenie, premyslenie, ale stretnutie znova rozbúrilo city, rozohrialo telá.

Erotická túžba je v texte znázornená ako pokušenie, ktoré sa spája s niečím nedovoleným, so zákazom a vinou. Výraznejšie je to reflektované cez postavu Ondra, ktorý si spočiatku praje, aby „sa telo pokušenia chcelo zbavit““. V prostredí prírody, kde nie sú sledovaní ostatnými a odbúrali sa vonkajšie „prekážky“ (matka, slúžka), si uvedomuje prirodzenost' a samozrejmost' toho, čo cítia a snaží sa o tom presvedčit’ aj Alenu. Popierat' lásku znamená „prikazovat' vlastnému srdcu, aby tíklo inak, ako má“ (Figuli 2011: 183) a naliehavost' tejto výpovede je v texte zvýraznená opakovaním. Ondro si uvedomí, že ovládnutie telesnej túžby je len dočasné, že vášeň je silnejšia a dokáže sa presadit' aj ,proti vôli človeka“. Praje si, aby pokušenie „odišlo“, „odtieklo prúdom ako zahodené kvety“, ale cíti, že „náruživost' ožíva“ a celý sa „stráca v prívale, v blaženom omotávaní každého kúska mäsa“. Sila túžby sa ukazuje vo vnútornom zápase. Je znázornená ako ohrozenie, pred ktorým chce „bránit”“ seba aj Alenu, a ako nepriatel', s ktorým chce „bojovat“", ale v skutočnosti z toho vyplynie len „boj proti sebe“. Napokon sa vášeň presadí a prejaví v plnej intenzite, čo Figuli znovu zachytila pomocou konceptu ohňa: „nový oheň žíha Ondrovo vnútro a spaluje mu mozog i srdce“. Aj Alena je po zobudení zohriata slnkom a jej ,pery zdajú sa ako okraje nádobky preplnenej túžbou“ (Figuli 2011: 186). V pozadí tohto obrazu je overená schéma zobrazovania tela ako nádoby pre emócie (Lakoff 2006: 370).

Figuli v novele Pokušenie prostredníctvom ženskej hrdinky nasvecuje lásku $\mathrm{v}$ troch rovinách $-\mathrm{v}$ rovine tela, ale aj $\mathrm{v}$ rovine mozgu/mysle a srdca. Pre Alenu je dôležitá dôvera, hlbší cit a nie nereflektované nasledovanie vášne. V texte je ale zdôraznená sila telesného zážitku, ktorý možno len oddialit'. Túžba má potenciál presadit' sa ako niečo pôvodné, prirodzené a nepotlačitel'né. 
Fyzické zblíženie Ondra a Aleny prináša zmenu, ktorá sa ukazuje aj vo vzájomnom oslovovaní - ak Alena v úvode novely konštatuje: „nebo vám vidím v očiach“, v závere túto vetu vyslovuje v pozmenenej podobe Ondro: „nebo ti vidím v očiach“. Zmena, ktorou postavy v priebehu novely prechádzajú je formou dozrievania a dospievania. $V$ texte je charakterizované ako prebratie, zobudenie či oživenie.

Na dotváranie atmosféry a nálady Figuli využíva pôsobivé poetické opisy prírody. Prírodné prostredie a cítenie postáv sú navzájom prepojené: veselá a idylická atmosféra na začiatku príbehu je badatel'ná v okolí: ,žltý ligotavý blyštek pustí sa do smiechu a rozochvieva na okolí trávu“. Zmenu nálady a tenziu, ktorú medzi pár vnieslo telesné pokušenie, reflektuje aj nebo „napäté st’a sval““. Nepokoj a Alenine obavy zrkadlí žalostenie hory, ktorá „hudie t'ahavo, a nevediet', či to ona tak l'udsky narieka, či niekoho vyvoláva, či niekoho oplakáva“" (Figuli 2011: 182).

\section{Extáza}

Aj komorne ladená novela Extáza (Figuli 2011: 65-75) ponúka bohaté opisy emocionálnych stavov postáv. Začína sa pozvaním Evice na narodeninovú oslavu $\mathrm{k}$ Pavlovičovcom. Pozvanie je však spojené so zámerom, aby sa spoznala s inžinierom Daňom, ktorý sa javí ako vhodný kandidát na manželstvo. Vytipovaný nádejný partner Evu síce zaujal, ale vnútorne ju takýto spôsob zoznámenia poburuje, takže Daňo u nej nemá šancu na úspech. Toto umelo organizované spoznávanie sa hrdinke pripomína „trh“, čo Figuli podčiarkla aj l'ahkou iróniou: „Najprv len myšlienkami vstupujem naň a morím sa hádankou, či pán si bude žičit’ telo, alebo dušu azda. Či obidvoje v krásnej, ideálnej predstave? Trh! No môj kupec, musím sa priznat', bol na závidenie stvorený človek“ (Figuli 2011: 65). Evica sa dostáva pod tlak. Daňo sa zdá byt’ zaujímavým partnerom s mnohými kvalitami, ale celá situácia v nej vyvoláva nepríjemné pocity, pretože sa cíti ako „tovar“. Aj myšlienky na manželstvo sú poznačené nevôl'ou. Budúcich partnerov - Daňa a seba - vníma ako vybrané kone z dobrého chovu: „Vraj môj budúci muž. Jasne som si predstavila tento manželský záprah dobre odchovaných koníčat. Chcelo sa mi zažalostit’ rehotom. Ach!“ (Figuli 2011: 68).

Sebavedomé komentovanie sa však deje len v rámci vnútorných monológov. V spoločnosti pri stole sa musí vyrovnat' s neustálym pozorovaním a hodnotením: „Tichá, bezradná dala som sa olizovat’ zvedavost'ou ostatných.“ Na otázku, či je spokojná s výberom partnera, reaguje zahanbene, červenaním sa, čo prerastie do pocitu, že ju zasiahol oheň: „Horela som pod dotieravými pohl'admi prítomných“ (Figuli 2011: 66). 
Z danej situácie ju zachráni stará pani Pavlovičová, hlavná hostitel'ka a oslávenkyňa, ktorá ju pozve, aby jej ukázala dar od syna - obraz visiaci vo vedl'ajšej miestnosti. Do diskusie o obraze sa po čase pripojí aj mladý Pavlovič. Rozhovor o maliarskom umení sa zvrtne k téme, ktorú rozoberá celé mesto, aj pozvaní hostia na oslave. Aféra mladého dievčat’a, ktoré sa zal'úbilo do ženatého nadriadeného, spôsobila rozpad rodiny a stretla sa s vel'kým odsudzovaním. Medzi Pavlovičom a Evicou sa rozvinie debata, ktorá na ňu bude mat' výrazný vplyv - v ten večer sa Evica zalúbi, no nie do vytipovaného partnera, ale do zadaného mladého spisovatel'a Pavloviča. Debata sa týkala lásky a cti. Pavlovič za čest' považuje prirodzené cítenie človeka a nie to, čo diktuje spoločenská norma, zákon. Evica mu protirečí: ,... akože možno slobodnému dievčat'u milovat' ženatého človeka?“ (Figuli 2011: 68), no už o krátku chvílu sama podl’ahne takémuto citu. Láska neskúsenú hrdinku prekvapí svojou nástojčivost’ou, túži sa dotknút' jeho úst: „hoci sa nerada bozkávam, potom som myslela už iba na akýsi požitok, ktorý nepoznám a ktorý naozaj jestvuje“ (Figuli 2011: 69). Zamilovanost’ spustí trýznivé riešenie morálnej dilemy. Evica prežíva drámu len vo svojom vnútri až do chvíle, ked' sa rozhodne svoju lásku priznat' v liste. Ten však nestihne odoslat', pretože Pavlovičovci odchádzajú po zvyšok prázdnin do letoviska mimo mesta.

Dôležitou emóciou textu je extáza, ktorá sa objavuje najprv v súvislosti s darovaným obrazom, na ktorom je zobrazená otrokyňa O-lan pohrúžená do meditatívneho stavu modlitby. Akt modlenia sa je nezvyčajne opísaný cez detail rúk a prstov: „Odovzdane preciedza cez prsty ruženec. Ruky má robustné, rozpl'asnuté st’a žilnatý, prezretý list.“ O-lan sa dostáva do stavu, v ktorom je oslobodená od svetských pokušení, do stavu opojenia modlitbou, extázy: „Priobyčajný tvor, ale v pohl’ade tajila povýšenost', odpútanie od svetských povol’ností. Akási nábožná extáza“ (Figuli 2011: $67)$.

Aj Evica sa dostáva do extázy, ale deje sa tak pri opätovnej návšteve, ked’ jej Pavlovič číta svoje básne o láske a chce počut jej názor na ne. Evica je zobrazená ako mladá, sebavedomá a vzdelaná žena s prehl'adom, ktorá dokáže viest' diskusie o umení, no v láske je neskúsená. Zakázané city k Pavlovičovi v nej vyvolávajú rozpor. Svoju extázu zažíva, pretože si mladého básnika vo svojej predstave povýšila, zbožštila: „Boh! Svojho som si vtedy zamenila za Pavloviča“" (Figuli 2011: 70).

Láska vyvolala v hlavnej hrdinke zmätok a rozhádzanie samozrejmých hodnôt: „rozum a cit zavliekli ma do chaosu prirodzenej cti a vymysleného zákona“ (Figuli 2011: 73). Pokúša sa urobit' eticky správne rozhodnutie, ale znamená to pre ňu vnútorný boj. Vzbudené city k Pavlovičovi vníma ako „nezmyselný prvý vír“, ktorý chce „zdolat'“ a „byt' statočná“. Na viacerých miestach postava reflektuje svoje prežívanie 
ako vnútorný konflikt, ktorý jej nedovolí spat: „Živý rozpor v duši šúlal mi hlavu po vankúšoch“ (Figuli 2011: 70).

Intenzita emócií Evicu prekvapí. City sú opísané ako voda, ktorá predstavuje dravý prúd pretekajúci jej telom: „Nemohla som bez pohnutia tušit’ dravý prúd všetkých tých citov, čo mali za ten čas pretiect’ mojím telom“ (Figuli 2011: 73). Citové pohnutie je v texte zachytené aj cez dynamický obraz „búrky, čo jej rozkolísala srdce“. Objavujú sa aj obrazy spútanosti a obmedzenia, ktoré sa asociujú so zákonom a spoločenskou povinnost’ou: „sputnaná zázračným povojníkom zákonov stojím povedl’a neho“, ale aj obrazy rozpútania, uvol’nenia: „rozbúrené živly duše (...) naraz rozviazali remence.“ Evine zatajené city náklonnosti k Pavlovičovi sú opísané ako „horenie“, ktoré navonok nevidno a sú prirovnané $\mathrm{k}$ jemnému vláknu pavučiny.

Zažívaná láska sa nespája len s pocitmi štastia vykresleného ako prameň, z ktorého možno pit', ale aj s bolestnými pocitmi: Ale čím tvrdohlavejšie pritkýnam si pery k prameňu tohto št’astia, tým viac sa morím. Trápenie je personifikované ako niekto, kto sa bezciel’ne pohybuje v priestore duše: „od tej chvíle poneviera sa mi trýzeň v duši“ či ako osoba, ktorá Evicu cielene sleduje: „, skutočnosti začala ma prenasledovat' akási bolest““.

Romantická láska hlavnej postavy sa končí náhle odchodom rodiny Pavlovičovcov do letoviska. Tento moment Figuli zobrazuje ako poškodenie krehkého objektu, ktorý sa rozbil: ,zaskučal zmar vo mne a čriepky roztíknutých citov padali ticho na dno mojej duše“ (Figuli 2011: 74).

\section{Záver}

Telo a emócie sú úzko prepojené. Prejavy emócií možno pozorovat'v správaní, gestách, vo vonkajších prejavoch (červenanie sa, zrýchlený dych) alebo vnútorne pocit’ovat'. Súvislosti tela s emóciami sú badatel'né aj v jazyku a v umeleckých textoch sú tvorivo spracované.

Z analýzy vybraných textov M. Figuli vyplýva, že rezonančným priestorom emócií je hlava, ale najmä konkrétnejšie pomenovaná tvár, oči a ústa (pery). $S$ láskou súvisí aj priestor hrudníka, pís a srdca. Z hl’adiska metaforiky je telesná a zmyslová skúsenost' človeka zásadná. S láskou a vášňou sa spája predovšetkým ohnivost', horúčost' a búrlivost'. Na druhej strane nedostatok či slabšia intenzita citov korešponduje s chladom a meravostou. Láska a city majú aj fluidný charakter a v texte sú vyjadrené ako tečenie. 
M. Figuli okrem bohatej obraznosti pracuje s rytmom slov a viet a na zosilnenie emotivity funkčne využíva opakovanie. Poeticky ladené opisy prostredia korešpondujú s citovými stavmi postáv.

\section{Summary}

Two novellas Temptation (Pokušenie) and Ecstasy (Extáza) written by Margita Figuli in 1937 are analysed in the presented article. The focus is on the relationship between the body and emotions and their expression through metaphors. Several such metaphors of emotions (love, passion, weak emotional response, absence of emotional reactions) are identified, linked to the body (head, eyes, mouth, lips, breast, hearth) or natural phenomena (heat, fire, storm, fluid, cold, stiffness), and discussed in detail.

\section{Literatúra}

Čepan, O. Kontúry naturizmu. Bratislava: Slovenský spisovatel', 1977.

Figuli, M. Výber z diela. Bratislava: Kalligram - Ústav slovenskej literatúry SAV, 2011.

Kövecses, Z. Metaphor and Emotion: Language, Culture, and Body in Human Feeling, Cambridge University Press, 2000.

Lakoff, G. Ženy, oheň a nebezpečné věci: co kategorie vypovídají o naší mysli. Praha: Triáda, 2006.

Lakoff, G., Johnson, M. Metafory, kterými žijeme. Brno: Host, 2002.

Šútovec, M. Doslov. In: Figuli, M. Výber $z$ diela. Bratislava: Kalligram - Ústav slovenskej literatúry SAV, 2011, s. 463-479.

Š́tovec, M. Mýtus a dejiny v próze naturizmu. Bratislava: Literárne informačné centrum, 2005.

Winko, S. Kodierte Gefühle. Zu einer Poetik der Emotionen in lyrischen und poetologischen Texten um 1900. Berlin: Erich Schmidt, 2003. 